\title{
PENGEMBANGAN MODUL KONTEKSTUAL ARITMATIKA SOSIAL KELAS 7 SMP
}

\author{
Rizki Nurhana Friantini ${ }^{1}$, Rahmat Winata ${ }^{2}$, Jeliana Intan Permata ${ }^{3}$ \\ ${ }^{1,2,3}$ Program Studi Pendidikan Matematika STKIP Pamane Talino, J1 Afandi Rani Jalur 2 Ngabang Kabupaten Landak \\ Kalimantan Barat \\ keyheart1315@gmail.com
}

\begin{abstract}
The purpose was to develop contextual-based mathematics learning module on Social Arithmetic material for grade VII junior high school. This type of research is research and development. Contextual-based module development is done so that students can understand and interpret learning independently. The model used to develop the module is the Borg and Gall model which consists of: 1) Preliminary studies and data collection, 2) Module preparation, 3) Module validation and revision, 4) FGD, 5) Revision of FGD results, 6) Initial field trials, 7) Improvement of initial field trial product, 8) Field implementation tests, and 9) Revision of field implementation test results. The population in this study was VII grade students. Data collection instruments using a teacher response questionnaire, student readability questionnaire, student response questionnaire, and learning achievement test. The results of this study are product what is Social Arithmetic Contextual module. From the results of the student response questionnaire, it was found that module had a very good category for the module components as well as a good category for the module presentation module and the module benefits when used in learning. While the results of the hypothesis test obtained that $t_{\text {count }}=3.806>t_{\text {table }}=$ 1.669 so that the Social Arithmetic Contextual module is effective to use.
\end{abstract}

Keywords: Research and development; Module; Contextual; Social Arithmetic

\begin{abstract}
Abstrak
Tujuan penelitian adalah mengembangkan modul pembelajaran matematika berbasis kontekstual pada materi Aritmatika Sosial untuk siswa kelas VII SMP. Pengembangan modul berbasis kontekstual dilakukan agar siswa dapat memahami dan memaknai pembelajaran secara mandiri. Jenis penelitian ini adalah research and development. Model yang digunakan untuk mengembangkan modul adalah model Borg dan Gall yang terdiri dari: 1) Studi pendahuluan dan pengumpulan data, 2) Persiapan modul, 3) Modul validasi dan revisi, 4) FGD, 5) Revisi hasil FGD, 6) Uji coba lapangan awal, 7) Peningkatan produk uji coba lapangan awal, 8) Uji implementasi lapangan, dan 9) Revisi hasil uji implementasi lapangan. Populasi dalam penelitian ini adalah siswa kelas VII SMP Santo Thomas Ngabang. Instrumen pengumpulan data dengan menggunakan angket respons guru, angket keterbacaan siswa, angket respons siswa, dan tes prestasi belajar. Hasil dari penelitian ini adalah produk berupa modul Kontekstual Aritmetika Sosial. Dari hasil angket respon siswa, ditemukan bahwa modul memiliki kategori yang sangat baik untuk komponen modul serta kategori yang baik untuk modul presentasi modul dan manfaat modul ketika digunakan dalam pembelajaran. Sedangkan hasil uji hipotesis diperoleh bahwa $t_{\text {hitung }}=3,806>t_{\text {tabel }}=1,669$ sehingga modul Kontekstual Aritmetika Sosial efektif digunakan.
\end{abstract}

Kata kunci: Pengembangan; Modul; Kontekstual; Aritmatika Sosial

\section{PENDAHULUAN}

Matematika merupakan salah satu mata pelajaran yang penting dan bermanfaat pada kehidupan sehari-hari. Berhitung, operasi bilangan, untung dan rugi, semua itu diterapkan langsung di kehidupan. Pada abad ke-21 ini, matematika telah menjadi alat untuk penemuan prinsip sains baru, dasar-dasar pengembangan komputer, pengaturan lalu lintas dan komunikasi, penggunaan energi atom, peramalan cuaca, navigasi angkasa luar, dan lain-lain. Beberapa contoh tersebut membutktikan matematika banyak memberi kontribusi dan manfaat dalam kehidupan manusia baik secara langsung 
maupun tak langsung (Santi \& Santosa, 2016). Tetapi pada kenyataannya matematika masih menjadi mata pelajaran yang tidak disukai karena siswa menganggap matematika sulit. Anggapan itu yang menyebabkan siswa malas dan enggan untuk belajar matematika.

Dari observasi di kelas VII SMP Santo Thomas Ngabang tahun ajaran 2019/2020 diketahui bahwa guru masih sering menggunakan metode pembelajaran klasik, sehingga kurang diskusi dan latihan soal karena guru terfokus pada penyelesaian penyampaian materi sehingga siswa menjadi bosan dan malas untuk belajar matematika. Siswa tidak dilibatkan secara aktif dan pembelajaran matematika yang dilakukan guru juga kurang dihubungkan dengan dunia nyata. Kemampuan penguasaan matematika siswa yang kurang membuat prestasi siswa menjadi rendah. Belajar didefinisikan sebagai konstruksi pengetahuan oleh individu. Ini adalah sebuah proses interaktif yang melibatkan konstruksi pengetahuan oleh individu melalui kerja sama sosial yang terjadi melalui interaksi kelompok (Ponnambaleswari, 2012). Oleh karena itu dalam pembelajaran sebaiknya lebih ditekankan untuk siswa mengkontruksi sendiri pengetahuannya baik secara individu maupun kelompok sehingga siswa lebih mampu menguasai materi dan meningkatkan prestasi. Dari segi fasilitas pembelajaran, sudah cukup memadai, hanya saja pilihan bahan ajar yang digunakan masih sedikit. Pembelajaran mempunyai arti proses, cara, perbuatan mempelajari. Pada pembelajaran, guru mengajar diartikan sebagai upaya guru mengorganisir lingkungan terjadinya pembelajaran, guru menyediakan fasilitas belajar bagi siswanya untuk mempelajarinya (Suprijono, 2012), sehingga dalam pembelajaran guru harus kreatif dan inovatif dalam menyediakan bahan ajar sebagai fasilitas siswa dalam mengkontruksi pengetahuannya.

Bahan ajar adalah segala bentuk bahan yang digunakan oleh guru dalam melaksanakan kegiatan belajar mengajar di kelas yang disusun secara sistematis baik tertulis maupun tidak tertulis sehingga tercipta lingkungan atau suasana yang memungkinkan siswa untuk belajar (Hamdani, 2011). Oleh karena bahan ajar berfungsi untuk membantu guru dalam melaksanakan pembelajaran, ada baiknya bahan ajar yang digunakan lebih dikembangkan. Pengembangan buku ajar adalah suatu proses sistematis, efektif, dan efisien dalam menciptakan sistem instruksional untuk memecahkan masalah belajar atau meningkatkan kinerja siswa melalui serangkain kegiatan pengidentifikasian masalah, mengembangkan, dan pengevaluasian (Suparman, 2012). Pengembangan bahan ajar bisa disesuaikan dengan model atau pendekatan yang dapat membangun pengetahuan dan pemahaman siswa sehingga tujuan dari pembelajaran dapat tercapai. Salah satu bentuk bahan ajar yang dapat digunakan dalam pembelajaran yaitu modul. Kurangnya variasi fasilitas bahan ajar yang digunakan guru berdasarkan hasil observasi dapat diatasi dengan pengembangan modul pembelajaran.

Modul merupakan bahan ajar yang berbentuk buku yang ditulis dengan tujuan siswa dapat belajar mandiri. Menurut Endang, dkk. (2016) modul adalah panduan ajar yang disusun secara sistematis dan menarik yang mencakup isi materi, metode, dan evaluasi yang dapat digunakan secara mandiri (Anugrahana, 2019). Suatu modul merupakan buku yang ditulis dengan tujuan agar siswa dapat belajar secara mandiri tanpa atau dengan bimbingan guru (Majid, 2009). Modul dapat 
dirumuskan sebagai suatu unit yang lengkap yang berdiri sendiri dan terdiri atas suatu rangkaian kegiatan belajar yang disusun untuk membantu siswa mencapai sejumlah tujuan yang dirumuskan secara khusus dan jelas (Nasution, 2011).

Tujuan penyusunan modul adalah menyediakan bahan ajar yang sesuai dengan tuntutan kurikulum dengan mempertimbangkan kebutuhan siswa, yakni bahan ajar yang sesuai dengan karakteristik materi ajar dan karakteristik siswa, serta setting atau latar belakang lingkungan sosialnya serta dapat membelajarkan siswa sesuai pendapat Harold Spears yaitu belajar sebagai kegiatan yaitu kegiatan mengamati, membaca, berinisiasi, mencoba sesuatu sendiri, mendengarkan, mengikuti petunjuk (Hamdani, 2011). Selain itu pada bahan ajar berupa modul terdapat umpan balik dan tindak lanjut yang harus dilakukan siswa setelah mempelajari modul. Dengan demikian siswa dapat mengukur sendiri tingkat penguasaan materi yang dipelajari (Setyadi \& Saefudin, 2019). Prinsipprinsip dalam mengembangkan modul antara lain: 1) Disusun dari materi yang mudah untuk memahami yang lebih sulit, dan dari yang konkret untuk memahami yang semikonkret dan abstrak; 2) Menekankan pengulangan untuk memperkuat pemahaman; 3) Umpan balik yang positif akan memberikan penguatan terhadap siswa; 4) Memotivasi adalah salah satu upaya yang dapat menentukan keberhasilan belajar; 5) Latihan dan tugas untuk menguji diri sendiri (Hamdani, 2011). Modul yang dikembangkan sebaiknya disusun secara sistematik dimana terdiri dari petunjuk penggunaan, materi yang diberikan, soal latihan, dan kunci jawaban (Zamzam, 2020).

Salah satu pendekatan yang bisa digunakan untuk mengembangkan modul adalah kontekstual. Nurhadi menyatakan pendekatan kontekstual merupakan konsep belajar yang membantu guru mengaitkan antara materi yang diajarkannya dengan situasi dunia nyata siswa dan mendorong siswa membuat hubungan antara pengetahuan yang dimilikinya dengan penerapannya dalam kehidupan mereka (Winata et al., 2014). Kontekstual dalam pembelajaran memusatkan pada bagaimana siswa mengerti makna dari apa yang mereka pelajari, apa manfaatnya, dalam status apa mereka, bagaimana mencapainya dan bagaimana mereka mendemonstrasikan apa yang telah mereka pelajari (Suprijono, 2012). Dapat disimpulkan bahwa pembelajaran kontekstual adalah pembelajaran yang mempunyai konsep belajar mengaitkan antara materi yang diajarkan dengan situasi dunia nyata dan mendorong siswa membuat hubungan antara pengetahuan yang dimiliki dengan penerapan dalam kehidupan sehari-hari sehingga siswa dapat memaknai apa yang dipelajari. Keuntungan dari pembelajaran kontekstual adalah pembelajaran lebih bermakna dan produktif karena siswa melakukan aktivitas belajar baik fisik maupun mental untuk menemukan sendiri konsep dari materi pembelajaran (Yuniati, 2014).

Kontekstual melibatkan tujuh komponen utama pembelajaran efektif, yakni: konstruktivisme, bertanya, menemukan, masyarakat belajar, pemodelan, refleksi, dan penilaian sebenarnya (Riyanto, 2010). Konstruktivisme, pembelajaran harus dikemas menjadi proses mengkonstruksi atau siswa membangun sendiri pengetahuan mereka. Bertanya, kegiatan guru mendorong, membimbing, dan menilai kemampuan berpikir siswa serta cara siswa menggali informasi, mengonfirmasikan apa yang 
sudah diketahui, dan mengarahkan perhatian kepada aspek yang belum diketahuinya. Menemukan, kegiatan ini dari kontekstual yaitu pengetahuan dari keterampilan siswa dari hasil menemukan sendiri. Masyarakat belajar, hasil pembelajaran diperoleh dari kerja sama dengan orang lain yaitu melaksanakan pembelajaran dalam kelompok-kelompok belajar. Pemodelan, kegiatan ini dapat digunakan guru untuk memberi contoh cara mengerjakan sesuatu. Refleksi, membuat siswa merasa memperoleh sesuatu yang berguna tentang apa yang baru dipelajarinya. Penilaian sebenarnya, dilaksanakan selama dan sesudah proses pembelajaran berlangsung secara berkesinambungan.

Salah satu materi yang dapat dibawa ke dunia nyata adalah Aritmatika Sosial yang mempelajari mengenai nilai suatu barang, harga penjualan dan pembelian, persentase untung dan rugi, dan sebagainya. Aritmatika Sosial diajarkan di kelas VII SMP pada semester genap. Aritmetika sosial merupakan salah satu cabang ilmu matematika yang penggunaannya sangat erat dengan permasalahan kompleks dalam kehidupan sosial sehingga perlu menunjukkan secara nyata kepada siswa akan kebermaknaan materi Aritmetika Sosial untuk dipelajari. Oleh karena itu diperlukan suatu pendekatan pembelajaran yang dapat memberikan gambaran-gambaran nyata dan kebermanfaatan materi Aritmatika Sosial tersebut (Ramadhany \& Prihatnani, 2020). Hal tersebut dikarenakan dengan kontekstual pembelajaran berlangsung alamiah dalam bentuk kegiatan siswa bekerja dan mengalami, bukan hanya transfer pengetahuan dari guru ke siswa, sehingga hasil pembelajaran lebih bermakna bagi siswa (Arifin, 2016).

Berdasarkan hal-hal yang telah disebutkan membuat peneliti ingin meneliti mengenai pengembangan modul pembelajaran matematika berbasis kontekstual pada materi pokok Aritmatika Sosial SMP kelas VII. Dari penelitian ini diperoleh suatu produk berupa modul pembelajaran yang mempunyai spesifikasi yaitu: 1) modul dalam bentuk cetak, 2) modul berisi materi Aritmatika Sosial, dan 3) modul disajikan sesuai tujuh komponen pembelajaran kontekstual. Diharapkan dengan mengembangkan modul Kontekstual Aritmatika Sosial maka belajar akan lebih bermakna karena siswa mengalami apa yang dipelajarinya, bukan hanya sekedar mengetahuinya. Selain itu agar pembelajaran tidak hanya berorientasi target penguasaan materi yang diingat dalam jangka pendek, tetapi gagal dalam membekali siswa jangka panjang.

\section{METODE}

Jenis penelitian yang dilakukan adalah penelitian pengembangan. Penelitian pengembangan digunakan untuk menghasilkan produk tertentu dan menguji keefektifan produk tersebut (Sugiyono, 2010)._Menurut Borg dan Gall, penelitian pengembangan adalah suatu proses yang digunakan untuk mengembangkan atau memvalidasi produk yang digunakan dalam pendidikan dan pembelajaran (Fahmi \& Marsigit, 2014). Penelitian ini menggunakan model Borg dan Gall dengan langkah: 1) Studi pendahuluan dan pengumpulan data, pada langkah ini dilakukan analisis silabus dan buku panduan kurikulum 2013, sintaks/langkah dari pendekatan kontekstual, dan buku yang digunakan guru dalam 
pembelajaran matematika di kelas VII. Selain itu mengkaji materi Aritmatika Sosial sesuai dengan kurikulum 2013. 2) Penyusunan modul, pada langkah ini menyusun rancangan (draf) modul Kontesktual Aritmatika Sosial. Selain rancangan modul disusun juga instrumen baik instrumen penilaian modul maupun instrumen tes hasil belajar matematika pada materi pokok Aritmatika Sosial.

Untuk instrumen penilaian modul berupa instrumen validasi modul oleh ahli baik ahli materi maupun ahli media dan instrumen angket untuk guru dan siswa. 3) Validasi modul dilanjutkan revisi, modul yang sudah disusun selanjutnya divalidasi oleh para ahli, yaitu ahli materi dan ahli media yang kompeten di bidangnya. Modul yang sudah divalidasi oleh para ahli selanjutnya direvisi sesuai saran dan masukan para ahli hingga modul layak dan valid. 4) Focus Group Discussion (FGD), dilakukan dengan mengundang guru-guru matematika tingkat SMP dan sederajat untuk mengkritisi modul melalui lembar angket respon guru. 5) Revisi hasil FGD, peneliti menganalisis angket respon guru dan melakukan revisi sesuai saran dan pendapat dari para peserta FGD sehingga dihasilkan modul yang siap diuji coba di lapangan. 6) Uji coba lapangan awal, dilakukan dengan cara mengujicobakan modul kepada siswa SMP kelas VIII yang telah menempuh materi Aritmatika Sosial. Siswa dipilih berdasarkan kemampuan tinggi, sedang, dan rendah dengan tujuan agar modul dapat digunakan oleh seluruh siswa baik siswa yang berkemampuan tinggi, sedang, atau rendah. Peneliti memberikan angket yang berisi uji keterbacaan modul untuk siswa tersebut, nantinya dianalisis dan menjadi acuan untuk melakukan revisi kembali sebagai penyempurnaan modul. 7) Penyempurnaan produk hasil uji coba lapangan awal, revisi dan penyempurnaan produk dilakukan setelah pelaksanaan uji coba sehingga modul pembelajaran matematika berbasis kontekstual siap untuk diujicobakan di kelas pada materi pokok Aritmatika Sosial dan dapat diperoleh efektivitas modul tersebut pada pembelajaran. 8) Uji pelaksanaan lapangan, berkaitan dengan penggunaan modul pembelajaran matematika berbasis kontekstual yang sudah dikembangkan dan untuk mengetahui efektivitas modul yang dikembangkan tersebut pada pembelajaran matematika di kelas.

Uji efektivitas modul dengan menggunakan uji-t dilakukan dengan memberikan tes hasil belajar kepada siswa yang telah melaksanakan pembelajaran dengan menggunakan modul berbasis kontekstual. Dari hasil tes tersebut selanjutnya dianalisis untuk mengetahui efektif atau tidaknya modul pembelajaran matematika berbasis kontekstual yang sudah dibuat. 9) Revisi hasil uji pelaksanaan lapangan, tahap ini dilakukan dengan merevisi modul yang telah digunakan siswa dalam pembelajaran matematika yang disesuaikan dengan hasil analisis angket respon siswa terhadap penggunaan modul dalam pembelajaran di kelas. Berikut alur penelitian ini. 


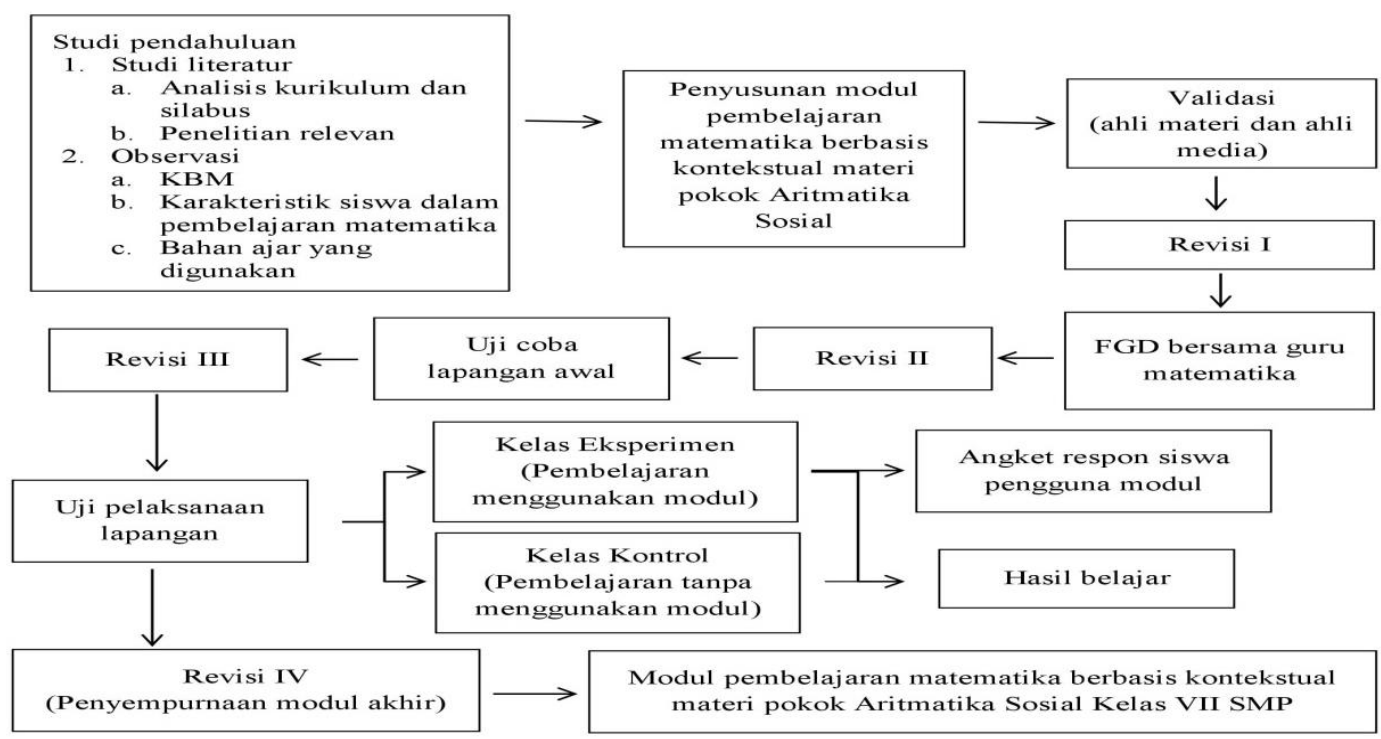

Gambar 1. Alur penelitian

\section{HASIL}

\section{Studi Pendahuluan dan Penyusunan Modul}

Studi pendahuluan mengenai tempat pelaksanaan penelitian dan observasi dilakukan di SMP Santo Thomas Ngabang tepatnya kelas VII. Observasi dilakukan terhadap pelaksanaan pembelajaran matematika dan buku yang digunakan guru dalam pembelajaran matematika. Untuk metode yang digunakan dalam pembelajaran matematika yang digunakan guru masih berupa metode pembelajaran klasik. Sedangkan buku yang digunakan guru masih terbatas dari segi kualitas dan kuantitas. Tetapi kurikulum yang diterapkan sudah menggunakan kurikulum 2013. Dalam penyusunan modul, mengkaji silabus matematika SMP berdasarkan kurikulum 2013 khususnya untuk materi Aritmatika Sosial yang terdiri dari beberapa bagian yaitu: keuntungan dan kerugian; bunga tunggal; serta tara, bruto dan netto sehingga modul ini dibuat menjadi tiga bab untuk masing-masing bagian tersebut.

Selain mengkaji silabus, dikaji juga mengenai sintaks dari pendekatan kontekstual yang terdiri dari tujuh komponen sehingga modul yang dibuat tentunya memuat semua komponen tersebut pada masing-masing babnya yaitu: konstruktivisme, bertanya, menemukan, masyarakat belajar, pemodelan, refleksi, dan penilaian sebenarnya. Garis besar susunan modul Kontekstual Aritmatika Sosial yaitu: sampul atau cover yang menggambarkan materi dan pendekatan pembelajaran yang digunakan, bagian dalam yang terdiri dari halaman sampul, kata pengantar, dan daftar isi, bagian inti yang terdiri dari pendahuluan dan kegiatan pembelajaran masing-masing bab, dan bagian akhir yang terdiri dari daftar pustaka. 


\section{Validasi modul}

Validasi yang dilakukan terdiri dari dua bagian yaitu validasi terhadap materi dan media. Validasi materi dan media dilaksanakan dengan memberikan modul yang sudah dibuat disertai lembar validasi yang berisi indikator penilaian terhadap modul. Validasi materi berkaitan dengan isi materi Aritmatika Sosial dengan pendekatan Kontekstual. Berikut indikator untuk validasi materi.

Tabel 1.

Indikator validasi materi

\begin{tabular}{|l|l|}
\hline \multicolumn{1}{|c|}{ Komponen } & \multicolumn{1}{c|}{ Indikator } \\
\hline Aspek Kelayakan Isi & Kesesuaian materi dengan KD \\
\cline { 2 - 2 } & Keakuratan materi \\
\cline { 2 - 2 } & Kemutakhiran materi \\
\cline { 2 - 2 } Aspek Kelayakan Penyajian & Materi mendorong keingintahuan \\
\cline { 2 - 2 } & Teknik penyajian \\
\cline { 2 - 2 } & Pendukung penyajian \\
\cline { 2 - 2 } & Keterlibatan siswa \\
\hline \multirow{5}{*}{ Aspek Kelayakan Bahasa } & Lugas \\
\cline { 2 - 2 } & Komunikatif dan Interaktif pikir \\
\cline { 2 - 2 } & Kesesuaian dengan perkembangan siswa \\
\cline { 2 - 2 } & Kesesuaian dengan kaidah bahasa \\
\cline { 2 - 2 } & Penggunaan istilah, simbol, atau ikon \\
\hline Aspek Evaluasi & Kesesuaian evaluasi dengan KD dan indikator \\
\cline { 2 - 2 } & Kalimat Soal \\
\hline Aspek Kontekstual & Hakikat realistik \\
\cline { 2 - 2 } & Karakteristik realistik \\
\hline
\end{tabular}

Validasi materi dilakukan dengan meminta bantuan validator yang dianggap ahli pada materi khususnya materi Aritmatika Sosial. Validator yang diminta menilai adalah dua dosen pendidikan matematika STKIP Pamane Talino dan satu guru mata pelajaran matematika SMP Santo Thomas Ngabang. Hasil dari validasi materi sebagai berikut.

\section{Tabel 2.}

Hasil validasi materi

\begin{tabular}{|l|c|c|l|}
\hline \multicolumn{1}{|c|}{ Komponen } & Jumlah Total & Jumlah Skor Maksimal & \multicolumn{1}{|c|}{ Kategori } \\
\hline Aspek Kelayakan Isi & 103 & 132 & Baik \\
\hline Aspek Kelayakan Penyajian & 108 & 132 & Sangat Baik \\
\hline Aspek Kelayakan Bahasa & 99 & 120 & Sangat Baik \\
\hline Aspek Evaluasi & 29 & 36 & Baik \\
\hline Aspek Kontekstual & 66 & 84 & Baik \\
\hline
\end{tabular}

Dari hasil validasi materi diperoleh bahwa modul mempunyai kategori baik untuk aspek kelayakan isi, aspek evaluasi, dan aspek kontekstual serta kategori sangat baik untuk aspek kelayakan penyajian dan kelayakan bahasa. Saran yang diberikan validator seperti latihan soal lebih dipermudah dan perbaikan pada sedikit pengetikan yang salah. 
Validasi media berkaitan dengan tampilan dan penyajian informasi pada modul. Validasi media dilakukan dengan meminta bantuan validator yang dianggap ahli pada media khususnya modul pembelajaran. Berikut indikator untuk validasi media.

Tabel 3.

Indikator validasi media

\begin{tabular}{|l|l|}
\hline \multicolumn{1}{|c|}{ Komponen } & \multicolumn{1}{c|}{ Indikator } \\
\hline Ukuran modul & Kesesuaian ukuran modul dengan standar ISO \\
\cline { 2 - 3 } & Kesesuaian ukuran dengan materi isi modul \\
\hline Desain sampul modul & Penampilan modul \\
\cline { 2 - 2 } & Warna modul \\
\cline { 2 - 2 } & Huruf yang digunakan \\
\cline { 2 - 2 } & Penggunaan kombinasi huruf \\
\cline { 2 - 2 } & Ilustrasi sampul modul \\
\hline Desain isi modul & Unsur tata letak harmonis \\
\cline { 2 - 2 } & Unsur tata letak lengkap \\
\cline { 2 - 2 } & Tata letak halaman \\
\cline { 2 - 2 } & Tipografi isi modul sederhana \\
\cline { 2 - 2 } & Ilustrasi isi \\
\hline
\end{tabular}

Validator yang diminta menilai adalah dua dosen pendidikan matematika STKIP Pamane Talino dan satu guru mata pelajaran matematika SMP Santo Thomas Ngabang. Hasil dari validasi media sebagai berikut.

\section{Tabel 4.}

Hasil validasi media

\begin{tabular}{|l|c|c|l|}
\hline Komponen & Jumlah Total & Jumlah Skor Maksimal & Kategori \\
\hline Ukuran Modul & 19 & 24 & Baik \\
\hline Desain sampul modul & 70 & 84 & Sangat Baik \\
\hline Desain isi modul & 118 & 156 & Baik \\
\hline
\end{tabular}

Dari hasil validasi media diperoleh bahwa untuk ukuran dan desain modul mempunyai kategori baik sedangkan desain sampul modul mempunyai kategori sangat baik. Saran yang diberikan validator pada aspek media seperti judul pada isi modul diperbesar agar lebih jelas dan modul lebih menggunakan warna yang bervariasi agar lebih menarik. Berdasarkan hasil validasi materi dan media disimpulkan bahwa modul sudah baik dan dapat digunakan dengan sedikit perbaikan berdasarkan saran yang diberikan validator.

\section{Focus Group Discussion (FGD) dan revisi}

FGD dilakukan dengan mengundang guru-guru matematika tingkat SMP di Kabupaten Landak yang berjumlah 6 orang. Pada FGD dibahas mengenai modul yang sudah diperbaiki berdasarkan hasil validasi materi dan media serta berdiskusi mengenai kekurangan atau apa yang perlu ditambahkan dari modul tersebut. Guru yang hadir juga mengisi angket respon guru untuk menilai modul. Hasil dari angket respon guru sebagai berikut. 
Tabel 5.

Hasil angket respon guru pada FGD

\begin{tabular}{|l|c|c|l|}
\hline \multicolumn{1}{|c|}{ Komponen } & Jumlah Total & Jumlah Skor Maksimal & Kategori \\
\hline Teknik Penyajian & 106 & 144 & Baik \\
\hline Kesesuaian Bahasa & 118 & 144 & Sangat Baik \\
\hline Kesesuaian Isi & 88 & 120 & Baik \\
\hline Kesesuaian Materi & 79 & 96 & Sangat Baik \\
\hline Kepraktisan dan kemudahan & 122 & 168 & Baik \\
\hline Aspek Kontekstual & 77 & 96 & Baik \\
\hline $\begin{array}{l}\text { Pengembangan kemampuan } \\
\text { berpikir }\end{array}$ & 130 & 168 & Baik \\
\hline
\end{tabular}

Dari hasil angket respon guru pada FGD dapat disimpulkan bahwa modul mempunyai kategori baik untuk teknik penyajian, kesesuaian isi, kepraktisan dan kemudahan, aspek kontekstual, dan pengembangan kemampuan berpikir serta mempunyai kategori sangat baik untuk kesesuaian bahasa dan kesesuaian materi. Sedangkan saran yang diberikan guru-guru saat berdiskusi seperti materi dipersingkat, bahasa yang digunakan lebih sederhana, dan soal yang diberikan lebih dipermudah. Saran tersebut selanjutnya digunakan untuk memperbaiki modul sehingga lebih baik lagi.

\section{Uji coba lapangan awal}

Pada uji coba lapangan awal, modul diujicobakan kepada siswa kelas VIII SMP Santo Thomas Ngabang yang telah mendapatkan materi Aritmatika Sosial. Siswa yang mendapatkan modul merupakan siswa yang mempunyai kemampuan tinggi, sedang, dan rendah agar dapat diketahui penggunaan modul pada setiap tingkat kemampuan siswa. Selanjutnya siswa mengisi angket keterbacaan modul untuk melihat apakah modul dapat terbaca dan digunakan dengan baik, dari hasil angket tersebut dilakukan perbaikan sehingga modul dapat diterima oleh semua siswa bagaimanapun kemampuannya. Hasil angket keterbacaan modul sebagai berikut.

Tabel 6.

Hasil angket keterbacaan modul

\begin{tabular}{|l|c|c|l|}
\hline Komponen & Jumlah Total & Jumlah Skor Maksimal & Kategori \\
\hline Ketertarikan & 452 & 560 & Baik \\
\hline Materi & 916 & 1120 & Sangat Baik \\
\hline Bahasa & 338 & 420 & Baik \\
\hline
\end{tabular}

Dari hasil angket keterbacaan modul diperoleh bahwa modul mempunyai kategori baik untuk komponen ketertarikan dan bahasa serta kategori sangat baik untuk kategori materi. Dari hasil tersebut dapat dilihat bahwa modul dapat dipahami dengan baik oleh siswa. Walaupun demikian saran yang diberikan siswa seperti gambar ilustrasi diperbanyak agar lebih menarik dan soalnya dipermudah tetap diterima dan dilakukan perbaikan pada modul untuk selanjutnya diujicobakan pada kelas VII. 


\section{Uji pelaksanaan lapangan dan revisi}

Pada uji pelaksanaan lapangan, modul diberikan kepada siswa kelas VIIB SMA Santo Thomas Ngabang sehingga ketika guru mengajarkan materi Aritmatika Sosial siswa menggunakan modul Kontekstual Aritmatika Sosial sebagai bahan pembelajaran. Pembelajaran dengan menggunakan modul Kontekstual Aritmatika Sosial dilaksanakan sebanyak 10 jam pelajaran. Dari pengamatan dilihat bahwa dengan menggunakan modul Kontekstual Aritmatika Sosial, siswa lebih semangat dan antusias untuk belajar. Setelah materi Aritmatika Sosial diajarkan, selanjutnya diberikan tes hasil belajar kepada siswa kelas VIIA dan VIIB dan angket respon kepada siswa kelas VIIB untuk mengetahui efektivitas modul Kontekstual Aritmatika Sosial pada pembelajaran.

\section{Tes hasil belajar siswa}

Tes diberikan di akhir materi Aritmatika Sosial pada siswa kelas VIIA yang tidak menggunakan modul Kontekstual Aritmatika Sosial dan siswa kelas VIIB yang menggunakan modul Kontekstual Aritmatika Sosial. Untuk tes hasil belajar, sebelum diberikan kepada siswa kelas VII terlebih dahulu tes hasil belajar diujicobakan di kelas VIII untuk dilakukan uji instrumen yang terdiri dari validitas isi, uji reliabilitas, uji tingkat kesukaran, dan uji daya beda dan telah memenuhi kriteria layak dari semua uji tersebut. Selanjutnya tes hasil belajar diberikan kepada siswa kelas VIIA dan VIIB dan memberikan hasil uji prasyarat sebagai berikut.

\section{Tabel 7.}

Hasil uji normalitas

\begin{tabular}{|l|r|r|r|r|r|r|}
\hline & \multicolumn{3}{|c|}{ Kolmogorov-Smirnov $^{\text {a }}$} & \multicolumn{3}{c|}{ Shapiro-Wilk } \\
\cline { 2 - 8 } & Statistic & \multicolumn{1}{c|}{ df } & \multicolumn{1}{c|}{ Sig. } & Statistic & \multicolumn{1}{c|}{ df } & \multicolumn{1}{c|}{ Sig. } \\
\hline VIIB &, 146 & 32 &, 082 &, 969 & 32 &, 486 \\
\hline VIIA &, 143 & 32 &, 093 &, 962 & 32 &, 313 \\
\hline
\end{tabular}

\section{a. Lilliefors Significance Correction}

Uji prasyarat yang pertama yaitu uji normalitas dengan menggunakan metode KolmogorovSmirnov. Dari hasil uji normalitas untuk kelas VIIB yang menggunakan modul memperoleh nilai sig $=0,082>0,05$ sehingga $\mathrm{H}_{0}$ diterima maka populasi berdistribusi normal. Sedangkan untuk kelas VIIA yang tidak menggunakan modul memperoleh nilai sig $=0,093>0,05$ sehingga $\mathrm{H}_{0}$ diterima maka populasi berdistribusi normal. Kedua kelas berasal dari populasi berdistribusi normal sehingga uji normalitas terpenuhi.

\section{Tabel 8.}

Hasil uji homogenitas

\begin{tabular}{|r|r|r|r|}
\hline $\begin{array}{c}\text { Levene } \\
\text { Statistic }\end{array}$ & \multicolumn{1}{c|}{ df1 } & \multicolumn{1}{c|}{ df2 } & \multicolumn{1}{c|}{ Sig. } \\
\hline $\mathbf{1 , 0 1 5}$ & 1 & 64 &, 317 \\
\hline
\end{tabular}


Uji prasyarat kedua yaitu uji homogenitas dengan menggunakan metode Levene. Dari hasil uji homogenitas diperoleh nilai sig $=0,317>0,05$ sehingga $\mathrm{H}_{0}$ diterima. Dari hasil tersebut dapat disimpulkan bahwa kedua kelas mempunyai variansi populasi yang homogen.

Setelah uji prasyarat terpenuhi, selanjutnya dianalisis uji hipotesis mengenai efektivitas modul Kontekstual Aritmatika Sosial pada pembelajaran. Analisis uji hipotesis ini diperoleh dari hasil tes hasil belajar yang diberikan kepada siswa kelas VIIA dan VIIB. Uji hipotesis menggunakan independent samples t-test dengan membandingkan hasil tes kelas VIIA yang tidak menggunakan modul dengan kelas VIIB yang menggunakan modul. Berikut hasil dari uji hipotesis.

\section{Tabel 9.}

Hasil uji hipotesis

\begin{tabular}{|l|c|c|c|c|r|r|r|r|r|}
\hline & \multirow{2}{*}{ F } & Sig. & $\mathbf{t}$ & df & $\begin{array}{c}\text { Sig. } \\
\mathbf{( 2 -} \\
\text { tailed) }\end{array}$ & $\begin{array}{c}\text { Mean } \\
\text { Difference }\end{array}$ & $\begin{array}{l}\text { Std. Error } \\
\text { Difference }\end{array}$ & \multicolumn{2}{|c|}{$\begin{array}{c}\text { In\% Confidence } \\
\text { Difference }\end{array}$} \\
\cline { 1 - 5 } & & & & & & & & Lower & Upper \\
\hline $\begin{array}{l}\text { Equal } \\
\text { variances } \\
\text { assumed }\end{array}$ & 1,015 &, 317 & 3,806 & 64 &, 000 & 7,15533 & 1,88024 & 3,39912 & 10,91155 \\
\hline $\begin{array}{l}\text { Equal } \\
\text { variances } \\
\text { not } \\
\text { assumed }\end{array}$ & & & 3,788 & 61,339 &, 000 & 7,15533 & 1,88879 & 3,37888 & 10,93179 \\
\hline
\end{tabular}

Berdasarkan hasil uji hipotesis menunjukkan bahwa $t_{\text {hitung }}=3,806>t_{\text {tabel }}=1,669$ berarti $t_{\text {hitung }} \in$ DK sehingga $\mathrm{H}_{0}$ ditolak. Dengan demikian dapat disimpulkan bahwa modul Kontekstual Aritmatika Sosial efektif digunakan dalam pembelajaran.

Angket respon siswa

Setelah menggunakan modul Kontekstual Aritmatika Sosial dalam pembelajaran, siswa kelas VIIB juga diberi angket respon siswa untuk mengetahui tanggapan siswa ketika menggunakan modul. Angket respon siswa ditinjau dari tiga komponen yaitu tampilan modul, penyajian modul, dan manfaat modul. Berikut hasil angket respon siswa.

Tabel 10.

Hasil angket respon siswa

\begin{tabular}{|l|c|c|l|}
\hline \multicolumn{1}{|c|}{ Komponen } & Jumlah Total & $\begin{array}{c}\text { Jumlah Skor } \\
\text { Maksimal }\end{array}$ & Kategori \\
\hline Tampilan modul & 69 & 84 & Sangat Baik \\
\hline Penyajian Modul & 94 & 120 & Baik \\
\hline Manfaat Modul & 118 & 156 & Baik \\
\hline
\end{tabular}

Dari hasil angket respon siswa diperoleh bahwa modul Kontekstual Aritmatika Sosial mempunyai kategori sangat baik untuk komponen modul serta kategori baik untuk komponen 
penyajian modul dan manfaat modul. Tidak ada perubahan atau perbaikan signifikan karena modul dapat digunakan dengan baik oleh siswa. Dapat disimpulkan secara umum bahwa pengembangan modul pembelajaran Kontekstual Aritmatika Sosial layak dan efektif untuk digunakan dalam pembelajaran matematika di kelas VII khususnya untuk mengajarkan materi Aritmatika Sosial.

\section{Modul Kontekstual Aritmatika Sosial}

Modul Kontekstual Aritmatika Sosial dibuat sesuai tujuh komponen pembelajaran kontestual. Tujuh komponen tersebut yakni: konstruktivisme, bertanya, menemukan, masyarakat belajar, pemodelan, refleksi, dan penilaian sebenarnya. Berikut beberapa gambaran dari modul Kontekstual Aritmatika Sosial yang dibuat.

\section{ARITMATLKA SOSIAL}

\section{Twiman Pam Godajaran:}

1. Siswa dapat mengenal dan menganalisis berbagai situasi terkait aritmatika sosia (penjualan, pembelian, potongan, keuntungan, kerugian, bunga tunggal, persentase, bruto, neto, tara).

2. Siswa dapat menyelesaikan masalah berkaitan dengan aritmatika sosial (penjualan, pembelian, potongan, keuntungan, kerugian, bunga tunggal, persentase, bruto, neto tara).

pakah kamu pernah pergi ke pasar? Pasar merupakan salah satu tempat terjadinya A kegiatan jual beli atau disebut juga perdagangan. Jika kita ingin memperoleh barang yang kita inginkan maka kita harus melakukan pertukaran untuk mendapatkannya. Misalnya penjual menyerahkan barang kepada pembeli yang disebut dengan istilah "jual" sebagai gantinya pembeli menyerahkan uang sebagai pengganti barang kepada penjual yang disebut dengan istilah "beli". Kegiatan "jual" dan "beli" adalah contoh dari aritmatika sosial. Aritmatika sosial merupakan salah satu materi matematika yang mempelajari operasi dasar suatu bilangan yang berkaitan dengan kehidupan sehari-hari. Pada bab ini akan dibahas lebih banyak lagi situasi berkaitan dengan aritmatika sosial.

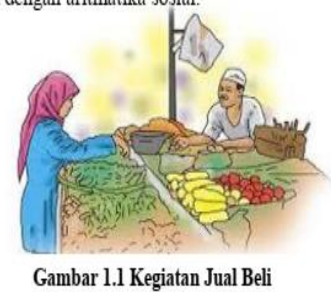

\section{A. Kenutungan dan Kerugian}

\section{Pamodeban}

Buatlah kelompok dengan beranggotakan 3-4 orang. Kemudian pilihlah yang berperan sebagai penjual dan pembeli. Peragakan percakapan di bawah ini! Jangan lupa bawa properti agar lebih nyata.

Narator : Pedagang ATK membeli pensil sebanyak 20 buah dengan harga $\mathrm{Rp}$ $25.000,00$ dan penghapus sebanyak 15 buah dengan harga $R p .12 .000,00$.

Penjual : Dijual-dijual pensil dengan harga Rp. 1.500,00 dan penghapus dengan harga Rp. 1.000,00. Ayo di beli

Pembeli 1 : Bang, beli pensil 8 buah dan penghapus 10 buah. Berapa ya totalnya?

Penjual : pensil 8 buah $x$ Rp. $1.500,00=R p \cdot 12 \cdot 000,00$ penghapus 10 buah $\times$ Rp. $1.000,00=R$. $10.000,00$ Total Rp. $22.000,00$

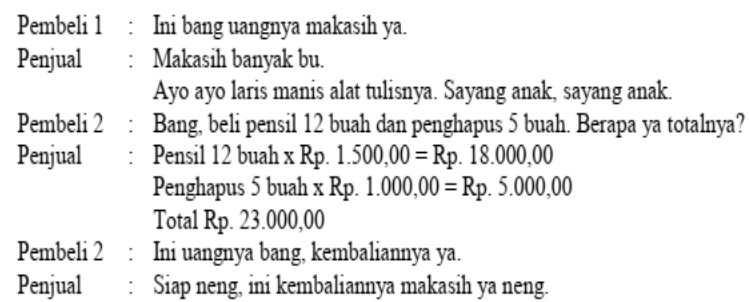

Peragakanlah dialog di atas dengan kelompok yang berbeda-beda. Jangan lupa hayati peran masing-masing.

Dialog percakapan di atas merupakan gambaran dari kegiatan jual beli yang berkaitan dengan aritmatika sosial.

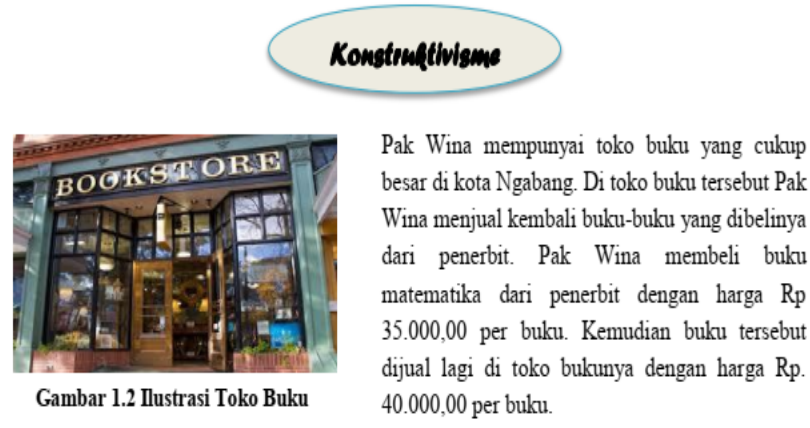

Dari kisah Pak Wina di atas dapat diketahui bahwa Pak Wina membeli buku matematika dan menjualnya kembali. Harga ketika Pak Wina membeli buku matematika disebut dengan Harga Beli sedangkan harga ketika Pak Wina menjual kembali buku matematika disebut dengan Harga Jual.

Harga Beli adalah harga pada waktu membeli suatu barang.

Harga jual adalah harga pada waktu menjual suatu barang.

Coba baca kembali ilustrasi cerita Pak Wina di atas.

Berapa harga beli satu buku matematika Pak Wina?

Berapa harga jual satu buku matematika Pak Wina?

Benar sekali! Harga beli satu buku matematika Pak Wina sebesar Rp 30.000,00 dan harga jual satu buku matematika Pak Wina sebesar $R p$ 40.000,00. Ternyata harga jual buku matematika lebih besar daripada harga belinya sehingga Pak Wina mendapatkan uang lebih

Gambar 2. Komponen pada modul Kontekstual Aritmatika Sosial 


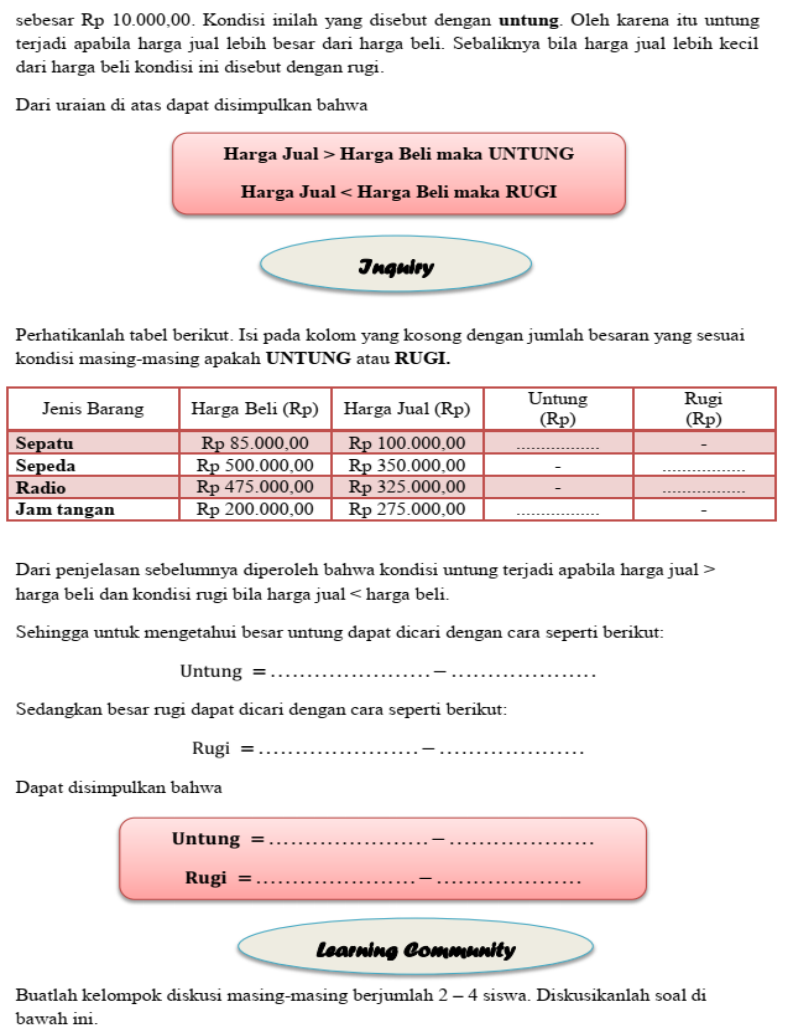
1. Pak Joko seorang penjual daging membeli daging $1 \mathrm{~kg}$ dengan harga Rp. $100.000,00$. Kemudian daging tersebut dijual dengan harga Rp. 120.000,00. Tentukan keuntungan yang diperoleh Pak Joko!
2. Seorang pedagang beras membeli beras $100 \mathrm{~kg}$ dengan harga Rp. 1.220.000,00. Kemudian beras tersebut dijual kembali dengan harga Rp. 13.000,00/kg. Tentukan keuntungan yang diperoleh!

Bila sudah yakin dengan jawabanmu, coba jelaskan langkah penyelesaian soal di atas kepada teman-temanmu

\section{Question}

Dalam perdagangan kita sering mendengar orang mengatakan "untung 5\%", "saya tidak ambil untung banyak hanya $2 \%$ ", atau "saya baru saja rugi $15 \%$ hari ini". Apa maksud dari pernyataan tersebut?

Dalam perdagangan yang dimaksud dengan untung $5 \%$ adalah mendapatkan keuntungan atau laba sebesar $5 \%$ dari harga belinya. Sedangkan rugi $15 \%$ berarti kerugian yang didapatkan sebesar $15 \%$ dari harga belinya.

Dapat dikatakan persentase untung atau rugi selalu dibandingkan terhadap harga beli atau modal awal sehingga diperoleh hubungan sebagai berikut.
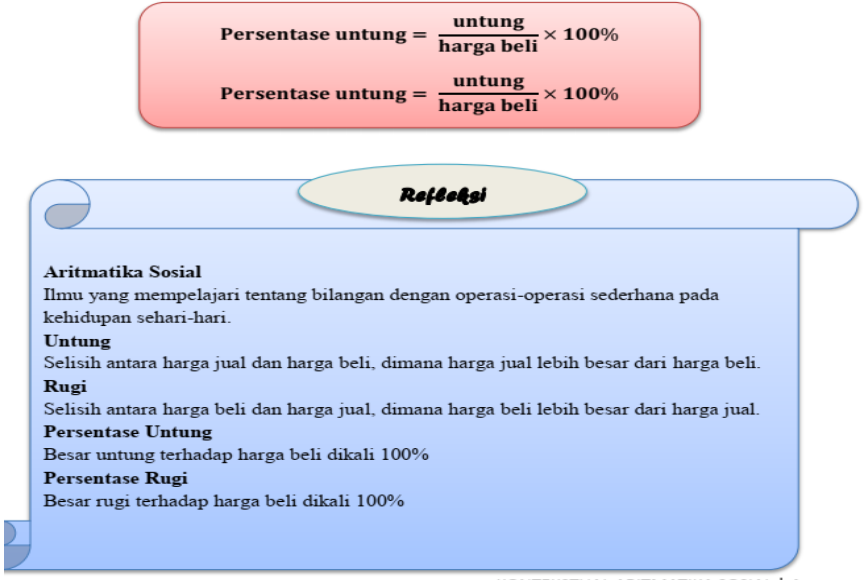

Gambar 3. Komponen pada modul Kontekstual Aritmatika Sosial

\section{KESIMPULAN}

Berdasarkan hasil penelitian dan pembahasan dapat disimpulkan bahwa pengembangan modul Kontekstual Aritmatika Sosial disesuaikan dengan silabus kurikulum 2013 materi Aritmatika Sosial dan langkah pembelajaran kontekstual. Dari hasil validasi materi diperoleh bahwa modul Kontekstual Aritmatika Sosial mempunyai kategori baik untuk aspek kelayakan isi, aspek evaluasi, dan aspek kontekstual serta kategori sangat baik untuk aspek kelayakan penyajian dan kelayakan bahasa. Dari hasil validasi media diperoleh bahwa modul Kontekstual Aritmatika Sosial mempunyai kategori baik untuk ukuran dan desain modul serta kategori sangat baik untuk desain sampul. Untuk angket respon guru pada FGD menghasilkan bahwa modul Kontekstual Aritmatika Sosial mempunyai kategori baik untuk teknik penyajian, kesesuaian isi, kepraktisan dan kemudahan, aspek kontekstual, dan pengembangan kemampuan berpikir serta mempunyai kategori sangat baik untuk kesesuaian bahasa dan kesesuaian materi. Untuk angket keterbacaan modul diperoleh bahwa modul Kontekstual Aritmatika Sosial mempunyai kategori baik untuk komponen ketertarikan dan bahasa serta kategori sangat baik untuk kategori materi. Serta hasil angket respon siswa diperoleh bahwa modul Kontekstual Aritmatika Sosial mempunyai kategori sangat baik untuk komponen modul serta kategori baik untuk komponen penyajian modul dan manfaat modul. Sedangkan dari hasil uji hipotesis diperoleh bahwa $t_{\text {hitung }}=3,806>t_{\text {tabel }}=1,669$ sehingga modul Kontekstual Aritmatika Sosial efektif untuk digunakan. Oleh karena itu dapat disimpulkan bahwa modul Kontekstual Aritmatika Sosial layak dan efektif digunakan dalam pembelajaran matematika. 


\section{UCAPAN TERIMA KASIH}

Terima kasih kami sampaikan kepada Direktorat Jenderal Penguatan Riset dan Pengembangan Kementerian Riset dan Teknologi/Badan Riset dan Inovasi Nasional atas segala dukungan dan bantuan dana yang diberikan kepada kami sehingga kami dapat menyelesaikan penelitian ini.

\section{DAFTAR PUSTAKA}

Anugrahana, A. (2019). Pengembangan Modul Sempoa Sebagai Alternatif Dalam Mata Kuliah Inovatif Matematika. Journal Cendekia: Jurnal Pendidikan Matematika, 3(2), 462-470.

Arifin, S. (2016). Penerapan Pendekatan Contextual Teaching And Learning (CTL) Untuk Melihat Kemampuan Komunikasi Matematis Mahasiswa Semester Awal Pendidikan Matematika UIN Raden Fatah. Jurnal Pendidikan Matematika JPM RAFA, 2(2), 142-160.

Fahmi, S., \& Marsigit. (2014). Pengembangan Multimedia Macromedia Flash dengan Pendekatan Kontekstual dan Keefektifannya terhadap Sikap Siswa pada Matematika. PYTHAGORAS: Jurnal Pendidikan Matematika, 9(1), 90-98.

Hamdani. (2011). Strategi Belajar Mengajar. Pustaka Setia.

Majid, A. (2009). Perencanaan Pembelajaran Mengembangkan Standar Kompetensi Guru. PT Remaja Rosdakarya.

Nasution, S. (2011). Berbagai Pendekatan dalam Proses Belajar \& Mengajar. Bumi Aksara.

Ponnambaleswari. (2012). Effectiveness of Cooperative Learning Strategy in facilitating Scholastic Achievement among Student-Teachers. International Multidisciplinary, 1(2), 29-37.

Ramadhany, A., \& Prihatnani, E. (2020). Pengembangan Modul Aritmetika Sosial Berbasis Problem Based Learning Bagi Siswa Smp. Jurnal Cendekia: Jurnal Pendidikan Matematika, 4(1), 212226.

Riyanto, Y. (2010). Paradigma Baru Pembelajaran: Sebagai Referensi bagi Pendidik dalam Implementasi Pembelajaran yang Efektif dan Berkualitas. Kencana Prenada Media Group.

Santi, I. . K. L., \& Santosa, R. H. (2016). Pengembangan Perangkat Pembelajaran Menggunakan Pendekatan Saintifik pada Materi Pokok Geometri Ruang SMP. PYTHAGORAS: Jurnal Pendidikan Matematika, 11(1), 35-44.

Setyadi, A., \& Saefudin, A. A. (2019). Pengembangan Modul Matematika Dengan Model Pembelajaran Berbasis Masalah Untuk Siswa Kelas VII SMP. PYTHAGORAS: Jurnal Pendidikan Matematika, 14(1), 12-22.

Sugiyono. (2010). Metode Penelitian Pendidikan: Pendekatan Kuantitatif, Kualitatif, dan R\&D. Alfa Beta.

Suparman, M. A. (2012). Desain Instruksional Modern. Erlangga.

Suprijono, A. (2012). Cooperative Learning: Teori dan Aplikasi PAIKEM. Pustaka Pelajar.

Winata, R., Budiyono, B., \& Usodo, B. (2014). Eksperimentasi Model Pembelajaran Kooperatif Tipe Numbered Heads Together (NHT) Dan Think Pair Share (TPS) Dengan Contextual Teaching And Learning (CTL) Pada Materi Persamaan Dan Pertidaksamaan Linear Satu Variabel Ditinjau Dari Kecerdasan Emosional Siswa. Jurnal Elektronik Pembelajaran Matematika, 2(5), 465-477.

Yuniati, S. (2014). Implementasi Pendidikan Karakter Dalam Pembelajaran Matematika Melalui Pendekatan Konstektual. Al-Khwarizmi, 2(1), 41-58. 
Zamzam, K. F. (2020). Pengembangan Modul Geometri Berbasis Reciprocal Teaching Untuk Meningkatkan Kemampuan Komunikasi Matematis Mahasiswa Calon Guru. Jurnal Cendekia: Jurnal Pendidikan Matematika, 4(1), 365-373. 